\title{
Pengaruh Motivasi dan Kepuasan Kerja pada Karyawan Generasi Millenial Terhadap Komitmen Organisasi pada PT Megaindo Gemilang Lestari
}

\author{
${ }^{1}$ Tobias Suprabowo, ${ }^{2}$ Winnie Minarni Muktar \\ Universitas Pelita Harapan, Jakarta, Indonesia
}

Email : ${ }^{1}$ tobiassuprabowo@gmail.com, 2winnieminarni@gmail.com

(Diterima: Oktober 2021; Direvisi: Oktober 2021; Dipublikasikan: Januari 2022)

\begin{abstract}
ABSTRAK
Tujuan penelitian ini untuk melihat apakah hubungan motivasi kerja dan kepuasan kerja karyawan pada PT Megaindo Gemilang Lestari (PT MGL) yang terletak di Jakarta memiliki pengaruh terhadap komitmen organisasi khususnya bagi karyawan generasi millennialnya. Metode dalam penelitian ini adalah kuantitatif. Instrumen pengumpulan data yang digunakan berupa kuesioner dengan teknik convenience sampling yang disebarkan kepada 100 karyawan generasi millennial PT MGL sebagai responden. Analisis dan interpretasi data menggunakan structural equation modeling (SEM) berbasis varians menggunakan metode pemodelan jalur partial least square (PLS). Berdasarkan hasil analisis didapat bahwa motivasi kerja memiliki pengaruh positif dan cukup signifikan terhadap komitmen organisasi. Kemudian variabel kepuasan kerja juga memiliki pengaruh positif dan signifikan terhadap komitmen organisasi. Berdasarkan pengukuran Rsquare motivasi kerja serta kepuasan kerja memiliki kontribusi signifikan terhadap komitmen organisasi karyawan generasi millennial pada PT MGL.
\end{abstract}

\section{Kata Kunci: Motivasi Kerja, Kepuasan Kerja, Komitmen Organisasi}




\section{PENDAHULUAN}

Semakin lama durasi waktu karyawan bekerja pada sebuah perusahaan, maka semakin berharga mereka bernilai bagi perusahaan tersebut. Karyawan mendapatkan semua pengalaman serta pengetahuan yang didapat selama bekerja di perusahaan (Hana dan Lucie, 2011). Terlebih lagi setiap organisasi pada era globalisasi saat ini harus memikirkan beberapa strategi untuk diterapkan pada semua generasi pekerja khususnya generasi millenial agar bisa meningkatkan komitmen organisasi guna mempertahankan karyawan mereka. Saat ini retensi pekerja millenial merupakan tantangan bagi organisasi (Thompson, 2012). Saat generasi baby boomers secara bertahap mulai memasuki tahap pensiun dan berhenti bekerja, maka generasi yang lebih muda yang disebut millenial akan menggantikan posisi mereka (Weirich, 2017).

Generasi millenial adalah kelompok generasi terbesar yang bekerja dalam perusahaan saat ini. Generasi Y, atau disebut juga generasi millenial, dikelilingi oleh berbagai informasi tentang kualitas hidup serta standar yang tinggi yang cenderung tidak realistis dan didasarkan oleh nilai profesional yang sebenarnya. Dengan demikian, para pimpinan dan departemen sumber daya manusia harus bisa memahami dan menghadapi tantangan kontemporer dari karyawan yang ada di generasi ini agar bisa mempertahankan dan memotivasi mereka (Diskiené et al., 2017). Perusahaan juga perlu memahami bahwa generasi millenial merupakan pekerja keras namun mereka sangat menghargai waktu luang dibandingkan dengan generasi sebelumnya (Meriac et al., 2010; Becton et al., 2014).

Wood, J. C. (2019) menyatakan bahwa ada alasan lain mengapa umumnya generasi millenial cenderung tidak memiliki loyalitas yang tinggi terhadap pekerjaannya ataupun perusahaan tertentu. Alasan tersebut adalah bahwa mereka tidak akan berada dalam situasi pekerjaan yang membuat mereka tidak merasa nyaman. Berdasarkan adanya kemudahan akses internet juga mempermudah mereka untuk mendapatkan berbagai informasi. Oleh sebab itu, organisasi perlu memahami karyawan generasi millenial agar dapat membuat strategi untuk meningkatkan komitmen organisasi yang ada di perusahaan.

Berdasarkan Maume (2006) komitmen organisasi biasanya diukur dengan item yang menyentuh kesediaan responden untuk bekerja keras dalam meningkatkan perusahaan mereka bekerja, serta loyalitas atau kebanggaan karyawan untuk bekerja terhadap perusahaan. Dalam hal meningkatkan komitmen organisasi tentunya motivasi kerja yang baik dan kepuasan kerja karyawan yang bisa dipertahankan memainkan peran yang penting. Menurut Siswanto (2005) dalam bukunya Manajemen Keuangan, ada beberapa poin untuk mencapai stimulus yang bisa mempengaruhi motivasi dan perilaku seseorang dalam organisasi. Seperti apakah pekerjaan mereka saat ini sudah sesuai dengan yang mereka harapkan, bagaimana mereka bisa mengembangkan dirinya saat bekerja di perusahaan atau diikutsertakan 
dalam pengambilan keputusan penting dalam organisasi.

Selain itu, faktor penting lainnya adalah kepuasan kerja. Seperti penelitian yang dilakukan oleh Robbins (2018) diketahui bahwa karyawan atau pekerja yang memiliki tingkat kepuasan kerja yang tinggi akan memiliki perasaan positif terhadap pekerjaannya dan juga sebaliknya. Hasil penelitian dari Ahmed, M. (2017) juga menunjukkan bahwa motivasi kerja khususnya mempelajari hal baru dengan adanya pelatihan, kepuasan kerja, dukungan dari organisasi serta budaya belajar dalam organisasi memiliki hubungan positif dan signifikan terhadap komitmen organisasi.

Setelah melakukan diskusi dengan pihak PT Megaindo Gemilang Lestari, didapat bahwa belakangan terdapat beberapa karyawan yang kinerjanya menurun. Dimulai dari tingginya absensi dan banyaknya komplain dari bagian HRD. Selain itu, turnover yang terjadi belakangan juga cukup tinggi. Karyawan yang sebelumnya sudah lama bekerja mengatakan bahwa dirinya masih merasa kurang puas dengan kebijakan perusahaan.

Penelitian ini memiliki tujuan untuk melihat apakah motivasi kerja dan kepuasan kerja karyawan pada PT Megaindo Gemilang Lestari yang terletak di Jakarta memiliki pengaruh yang signifikan terhadap komitmen organisasi khususnya bagi karyawan atau pekerja generasi millenialnya.

Hasil dari penelitian ini diharapkan dapat memberikan wawasan tambahan maupun referensi sebagai dasar penelitian atau studi lebih lanjut. Kemudian hasil penelitian ini juga diharapkan bisa berkontribusi memberikan saran dan digunakan oleh para praktisi HR maupun perusahaan yang ingin mengetahui tentang hubungan antara motivasi dan kepuasan karyawan terhadap komitmen organisasi khususnya pada generasi millennial.

\section{TINJAUAN PUSTAKA}

\section{Generasi Millenial}

Generasi Millenial terdiri dari orang - orang yang lahir dari tahun 1981 sampai 1996, atau generasi yang berumur 25 sampai 41 tahun pada tahun 2021. Sementara orang - orang yang lahir pada tahun 1997 dan setelahnya dapat dikategorikan sebagai generasi Z (Dimock, M., 2019). Generasi Millennial dibentuk oleh perkembangan teknologi informasi yang masif, peningkatan jejaring sosial, dan budaya global yang terhubung satu dengan yang lainnya. Meskipun kadang-kadang generasi tersebut dicap sebagai generasi yang tidak sabar, mudah terganggu, terlalu banyak bersosialisasi, dan merasa memiliki hak berlebih, generasi millennial juga dapat dicirikan sebagai generasi yang sangat berdaya, kolaboratif, dan inovatif (Waljee, J. F., Chopra, V., \& Saint, S., 2020). Generasi Millennial juga adalah generasi yang memiliki beragam faktor motivasi dalam lingkungan kerjanya dimana perusahaan tidak bisa menerapkan satu strategi yang sama untuk semua pekerja generasi tersebut, melainkan harus mengidentifikasi keunikan dari setiap karyawan pada generasi ini yang jika dilakukan dengan benar dapat menghasilkan banyak calon 
pemimpin - pemimpin baru (Calk, R., \& Patrick, A., 2017).

\section{Motivasi Kerja}

Motivasi dapat disebut
sebagai faktor pendorong
seseorang untuk melakukan
sebuah kegiatan dalam berprilaku
atau dalam melakukan sesuatu
(Sutrisno, 2019). Menurut Colquitt et al (2018), motivasi didefinisikan sebagai sekumpulan kekuatan energik yang berasal baik di dalam maupun di luar karyawan, memulai upaya terkait pekerjaan, dan menentukan arah, intensitas, dan ketekunan nya. Ada tiga teori di dalam penentuan motivasi ini, yaitu yang pertama adalah Expectancy theory, yang menjelaskan bahwa upaya diarahkan pada perilaku ketika upaya seseorang diyakini akan menghasilkan kinerja (expectancy), kinerja lalu diyakini akan menghasilkan hasil (instrumentality), dan hasil tersebut akan diantisipasi menjadi sesuatu hal yang bernilai (valence). Teori kedua adalah Goal Setting Theory, yaitu tujuan (goals) menjadi pendorong motivasi dan kinerja yang kuat ketika target kerja sulit dan spesifik. Sasaran yang spesifik dan sulit mempengaruhi kinerja dengan meningkatkan sasaran yang ditetapkan sendiri dan strategi kerja. Efek tersebut lebih sering terjadi ketika karyawan diberikan umpan balik, tugas yang tidak terlalu kompleks, dan tujuan dengan kebutuhan komitmen yang tinggi. Lalu teori yang ketiga adalah Equity Theory, yang menjelaskan imbalan itu adil ketika rasio hasil seseorang terhadap masukan cocok dengan beberapa perbandingan yang relevan lainnya. Rasa ketidakadilan memicu tekanan ekuitas. Ketidakadilan yang kurang menguntungkan biasanya menghasilkan tingkat motivasi yang lebih rendah atau tingkat perilaku tidak produktif yang lebih tinggi. Ketidakadilan yang berlebihan biasanya menghasilkan distorsi kognitif, dimana masukan dievaluasi ulang dengan cara yang lebih positif.

Motivasi juga ditentukan oleh stimulusnya, menurut Siswanto dalam bukunya Manajemen Keuangan (2005) mengungkapkan poin - poin untuk mencapai stimulus yang akan mempengaruhi motivasi dan perilaku seseorang di suatu organisasi, yaitu yang pertama adalah Kinerja (Achievement) bahwa kunci keberhasilan seseorang ditentukan oleh tingkat needs of achievement atau disingkat menjadi n-Ach yang sudah menjadi second nature atau naluri kedua seseorang. Dalam proses pencapaian targetnya, nAch dikaitkan dengan keberanian untuk mengambil calculated risk dan sikap positif seseorang. Lalu yang kedua adalah Penghargaan (Recognition) yang merupakan stimulus yang kuat untuk memberikan kepuasan batin yang lebih tinggi dalam bentuk pengakuan daripada pemberian dengan bentuk materi atau hadiah. Teori ketiga adalah tantangan (Challenge) dimana sasaran kerja yang tidak menantang atau dapat dilakukan dengan mudah tidak akan menjadi stimulus bagi 
seseorang, dan hanya akan menjadi kegiatan rutin yang membosankan. Tantangan akan menimbulkan kegairahan dan semangat untuk mengatasinya. Setelah itu teori keempat adalah Tanggung Jawab (Responsibility) yaitu rasa memiliki dan keikutsertaan dalam organisasi akan memotivasi seseorang untuk bertanggung jawab lebih tinggi. Lalu setelahnya teori kelima, yaitu Pengembangan (Development) yang akan menjadi stimulus bagi karyawan untuk bekerja lebih keras karena merasa kemampuannya juga diperhatikan dan ditumbuhkan di dalam organisasi. Lalu teori keenam adalah Keterlibatan (Involvement) yang akan menimbulkan kepuasan karena diikutsertakan dalam pengambilan keputusan penting dalam organisasi yang menumbuhkan motivasi karyawan. Teori terakhir adalah kesempatan (Opportunity) yang adalah kesempatan karyawan untuk maju ke jenjang karier yang terbuka dari tingkat bawah sampai atas yang akan memotivasi karyawan untuk bekerja lebih keras untuk naik tingkat.

Motivasi secara sederhana dapat dibagi ke dalam dua bentuk menurut Nawawi (2008), yaitu yang pertama adalah Motivasi Intrinsik, yang adalah pendorong untuk bekerja yang berasal dari dalam diri karyawan itu sendiri sebagai individu yang merupakan kesadaran dari dirinya akan kepentingan dan manfaat dari pekerjaan yang dikerjakannya. Dengan kata lain motivasi intrinsik ini bersumber dari pekerjaan yang dilaksanakannya karena menghasilkan kemampuan untuk memenuhi kebutuhan hidup, memberi rasa senang, ataupun memungkinkan karyawan tersebut untuk bisa mencapai tujuan hidupnya dan bisa memberi harapan positif di masa depan. Lalu yang kedua adalah Motivasi Ekstrinsik, yaitu motivasi yang bersumber dari luar individu tersebut sebagai pekerja, yang berupa sebuah kondisi yang mengharuskan seseorang untuk melaksanakan pekerjaan tersebut secara maksimal, dapat berupa upah yang tinggi jika karyawan melakukan pekerjaan dengan dedikasi tinggi, mengejar jabatan yang lebih tinggi atau keinginan karyawan untuk mendapat kekuasaan yang lebih besar dari sebelumnya.

\section{Kepuasan Kerja}

Kepuasan kerja dapat didefinisikan sebagai sebuah perasaan yang positif yang berkaitan dengan suatu pekerjaan yang dihasilkan dari evaluasi karakteristik seseorang. Seseorang yang memiliki kepuasan kerja tinggi memiliki perasaan yang positif terhadap pekerjaannya, dan juga berlaku sebaliknya. Kepuasan kerja seseorang di tempatnya bekerja dapat disebabkan oleh berbagai hal, seperti kondisi tempat bekerja, kepribadian dari karyawan tersebut dan rekan kerjanya, gaji yang diperoleh, dan tindakan corporate social responsibility yang dilakukan oleh perusahaan. (Robbins, Stephen P., Timothy A. Judge, 2017).

Menurut Luthans (2010), kepuasan kerja seorang karyawan 
dipengaruhi oleh lima dimensi, yang pertama adalah The work itself, yaitu sejauh mana pekerjaan tersebut memberi individu tugas yang menantang, kesempatan untuk belajar, dan juga kesempatan dalam menerima tanggung jawab. Setelah itu yang kedua adalah Pay, dimana jumlah upah atau keuntungan karyawan yang diterima dan sejauh mana hal ini dipandang adil dibandingkan dengan orang lain dalam organisasi di tempat mereka bekerja. Lalu ketiga adalah Promotion Opportunities yaitu kesempatan bagi karyawan untuk bisa berkembang dalam jenjang karir merupakan salah satu penentu kepuasan kerja karyawan. Teori keempat adalah Supervision, adalah kemampuan penilaian dan koreksi di dalam pekerjaan karyawan yang bertujuan untuk mendapat keyakinan bahwa tujuan dan juga rencana yang akan dicapai telah dikerjakan dengan baik dan benar. Teori kelima adalah Co-Workers, adalah interaksi sosial antar sesama pekerja atau dengan pimpinan secara suportif dan baik yang berdampak kepada kepuasan karyawan.

\section{Komitmen Organisasi}

Komitmen organisasi
dipandang sebagai
"kecenderungan untuk 'terlibat
dalam jalur aktivitas yang
konsisten' berdasarkan pengakuan
individu atas 'cost' (atau lost side
bets) yang terkait dengan
penghentian aktivitas" menurut
penelitian berjudul the
measurement and antecedents of
affective, continuance, and

normative commitment to the organization. Journal of Occupational Psychology (Allen, N. J. ad Meyer, J. P., 1990). Komitmen organisasi juga merupakan sebuah konsep yang penting karena mempengaruhi komitmen pada karyawan, organisasi, dan masyarakat secara keseluruhan. Karyawan bisa mendapatkan keuntungan dari komitmen menggunakan penghargaan intrinsik dan ekstrinsik yang relevan dengan organisasi (Buchko, A. A., 1998). Selain itu menurut Maxwell (2013), komitmen pada organisasi juga dapat melibatkan tiga faktor. Faktor pertama adalah kuatnya keyakinan dan penerimaan terhadap tujuan dan nilai organisasi, dilanjutkan dengan faktor yang kedua adalah keinginan untuk memberi upaya yang cukup besar untuk organisasi. Lalu faktor yang ketiga adalah kemauan dalam mempertahankan status keanggotaan di dalam organisasi.

Meskipun komitmen organisasi memiliki beberapa klasifikasi yang berbeda, penelitian yang dilakukan oleh Meyer dan Allen (1997) juga menjabarkan tiga jenis komitmen organisasi, jenis yang pertama adalah Komitmen Afektif, berarti kepuasan individu dengan organisasi dan kepuasan menjadi anggota organisasi. Dengan kata lain, komitmen afektif mengacu pada dedikasi karyawan pada organisasi. Lalu yang kedua adalah Komitmen Normatif, yang mengacu pada pentingnya karyawan bagi organisasi. 
Karyawan dengan tingkat komitmen normatif tingkat tinggi merasakan bahwa mereka harus tetap berada di organisasi. Pada komitmen normatif, etos kerja dan budaya menyebabkan karyawan tersebut untuk bertahan dalam organisasi, akibatnya mereka merasa loyal terhadap organisasi dan tugas dapat mempengaruhi komitmen normatif karyawan. Dan yang ketiga adalah Komitmen Kontinuitas atau berkelanjutan yang mengartikan bahwa kebutuhan untuk tetap berada di organisasi karena karyawan dapat menghadapi konsekuensi jika mereka meninggalkan organisasi. Seperti jika karena mereka tidak mempunyai alternatif pekerjaan di tempat lain dan tidak ingin berganti pekerjaan, dan juga karyawan memilih untuk tetap berada di organisasi yang sama.

Kesimpulannya, karyawan yang memiliki komitmen afektif kuat bertahan dalam organisasi karena karyawan tersebut menginginkannya, mereka yang mempunyai komitmen kontinuitas yang kuat karena karyawan tersebut membutuhkan pekerjaan tersebut, sedangkan karyawan yang memiliki komitmen normatif yang kuat karena mereka merasa harus melakukannya karena tidak memiliki pilihan lain.

\section{METODE PENELITIAN}

\section{Populasi dan Sampel}

PT Megaindo Gemilang Lestari yang berlokasi di kota Jakarta yang merupakan perusahaan distributor mesin permainan arcade. PT Megaindo

Gemilang Lestari memiliki karyawan sebanyak 133 orang yang terdiri dari 43 karyawan perempuan dan 90 karyawan lakilaki yang menjadi populasi pada penelitian ini.

Sampel yang digunakan pada penelitian ini adalah karyawan dalam usia generasi millennial yaitu 25-40 tahun, penentuan jumlah sampel penelitian dilakukan dengan menggunakan metode Slovin. Dengan total populasi $(\mathrm{N})$ yaitu 133 karyawan dan batas toleransi error (e) sebesar 5\%, menggunakan rumus Slovin didapatkan jumlah sampel (n) adalah paling tidak 100 responden berdasarkan jabatannya sebagai karyawan (staff).

\section{Desain Penelitian}

Pendekatan pada penelitian ini menggunakan pendekatan kuantitatif untuk menguji hipotesis penelitian. Model pada penelitian ini menggunakan metode Partial Least Square Structural Equation Modelling (PLS-SEM). Tujuan dari penelitian ini adalah untuk mengetahui apakah peran motivasi dan kepuasan karyawan sebagai variabel independen dari generasi millennial memiliki pengaruh positif terhadap komitmen organisasi sebagai variabel dependen. Hasil dari penelitian ini dapat digunakan untuk mendukung penelitian lebih lanjut dan menjadi referensi pembaca, praktisi HR serta perusahaan di Jakarta. khususnya di bidang distributor mesin permainan arcade.

\section{Instrumen Pengumpulan Data}


Instrumen pengumpulan data yang digunakan dalam penelitian ini berupa kuesioner dengan teknik convenience sampling. Indikator - indikator yang digunakan dalam butir pertanyaan di dalam kuesioner mengukur peran motivasi kerja dan kepuasan kerja terhadap komitmen organisasi pada perusahaan yang diteliti. Seluruh indikator tersebut merupakan hasil dari pengembangan skala dengan skala pengukuran setiap butir pertanyaan kuesioner menggunakan empat poin skala Likert, yaitu $1=$ sangat tidak setuju, $2=$ tidak setuju, $3=$ setuju, dan 4=sangat setuju. Kuesioner kemudian disebarkan kepada 100 karyawan PT Megaindo Gemilang Lestari di Jakarta sebagai responden.

\section{Metode Analisis Data}

Penelitian ini menganalisis dan melakukan interpretasi data menggunakan structural equation modeling (SEM) berbasis varians menggunakan metode pemodelan jalur partial least square (PLS). Kemudian data diolah menggunakan software statistik SmartPLS 3.0 dalam model dan melakukan analisis hipotesis model persamaan struktural. Setelah itu instrumen diuji tingkat validitas dan reliabilitasnya dengan menggunakan analisis statistik PLS-SEM dengan tahap model pengukuran atau inner model. Pengujian tingkat validitas dilakukan dengan melakukan pengukuran nilai Average Variance Extraction (AVE), loading factor, serta discriminant analysis. Nilai dikatakan valid jika nilai discriminant analysis memenuhi kriteria FornellLarcker didapatkan yaitu nilai akar kuadrat AVE harus lebih besar daripada nilai korelasi antar variabel, dan nilai AVE $>0.5$, dan nilai loading factor $>0.7$. Setelah itu uji reliabilitas dilakukan dengan menghitung nilai composite reliability dengan nilai diatas 0.7 (Ghozali \& Latan 2015; Hair et al., 2014).

\section{Hipotesis Penelitian}

\section{Hubungan Motivasi Kerja dengan Komitmen Organisasi}

Dalam penelitian yang pernah dilakukan sebelumnya, diketahui beberapa elemen kunci yang dapat meningkatkan komitmen karyawan terhadap suatu organisasi. Faktor tersebut antara lain gaji dan upah, keamanan kerja, promosi, dan bonus, yang merupakan indikator dari motivasi kerja karyawan (Zameer et al., 2014). Motivasi juga menjadi sangat penting dalam meningkatkan komitmen organisasi di antara para pekerja, yang pada akhirnya mengarah pada tingkat produktivitas yang lebih tinggi. Dengan kata lain, karyawan yang berkomitmen cenderung menerima motivasi di tempat kerja dan dihargai atas prestasi yang baik (Srivastava, S. K., \& Barmola, K. C., 2012). Perusahaan yang menerapkan reward system untuk memberi motivasi lebih bagi karyawan yang produktif baik secara finansial maupun non finansial dalam rangka mendorong produktivitas karyawan serta meningkatkan loyalitas dan komitmen mereka terhadap organisasi (Hanaysha, J. 
R., \& Majid, M, 2018). Maka hipotesis dibuat berdasarkan pembahasan diatas yaitu:

H1: Motivasi Kerja memiliki pengaruh yang positif terhadap Komitmen Organisasi

Hubungan Kepuasan Kerja dengan Komitmen Organisasi

Kepuasan kerja memiliki dampak signifikan dengan faktor faktor seperti pertumbuhan karir, motivasi, lingkungan tempat kerja dan kepuasan diri (Rajput, S., Singhal, M., \& Tiwari, S., 2016). Semakin puas karyawan bekerja maka karyawan tersebut akan semakin berkomitmen pada perusahaan dan berlaku juga sebaliknya (Can, A., \& Yasri, Y., 2016). Setiap orang individu memiliki perbedaan tingkat kepuasan yang sesuai dengan nilai dari diri setiap orang individu tersebut, maka dari banyaknya aspek dalam pekerjaan yang sesuai dengan nilai dan keinginan individu tersebut yang dipenuhi oleh organisasi, akan membuat individu tersebut memiliki komitmen organisasi yang semakin kuat juga (Pratama, M. R. B., Al Musadieq, M., \& Nurtjahjono, G. E., 2017). Maka hipotesis dibuat berdasarkan pembahasan diatas yaitu:

H2: Kepuasan Kerja memiliki pengaruh yang positif terhadap Komitmen Organisasi

Ada tiga variabel yang menjadi fokus pada penelitian ini, yaitu motivasi kerja dan kepuasan kerja yang akan mempengaruhi variabel komitmen organisasi. Variabel pertama motivasi kerja dipengaruhi oleh indikator harapan, pengembangan, dan keterlibatan, sementara variabel kedua kepuasan kerja dipengaruhi oleh indikator penghargaan, pekerjaan itu sendiri, dan atasan atau rekan kerja di dalam penelitian ini. Peningkatan kedua variabel bebas tersebut akan berpengaruh kepada variabel ketiga yang bersifat terikat yaitu komitmen organisasi yang memiliki indikator kepatuhan, kesediaan bekerja keras, dan tanggung jawab ke perusahaan. Oleh karena itu, model penelitian dapat digambarkan sebagai berikut:

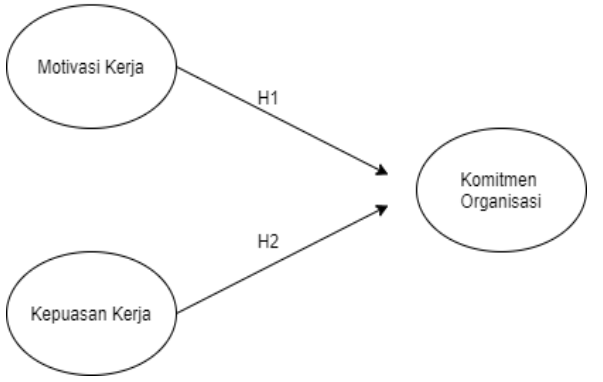

Gambar 1. Model Penelitian

\section{HASIL PENELITIAN}

1. Profil Responden

Tabel 1. Profil Responden

\begin{tabular}{|c|c|}
\hline Pernyataan & Jumlah Responden \\
\hline \multicolumn{2}{|l|}{ Jenis Kelamin } \\
\hline Pria & 71 \\
\hline Wanita & 29 \\
\hline \multicolumn{2}{|l|}{ Umur } \\
\hline 25 - 30 Tahun & 27 \\
\hline 31 - 35 Tahun & 38 \\
\hline 35 - 40 Tahun & 35 \\
\hline \multicolumn{2}{|l|}{ Posisi Pekerjaan } \\
\hline Karyawan & 93 \\
\hline Head Divisi & 4 \\
\hline Manager & 3 \\
\hline \multicolumn{2}{|c|}{ Durasi Bekerja Pada Perusahaan } \\
\hline Kurang dari 1 Tahun & 1 \\
\hline $1-3$ tahun & 23 \\
\hline Lebih dari 3 Tahun & 76 \\
\hline \multicolumn{2}{|c|}{$\begin{array}{l}\text { Profil responden dar } \\
\text { penelitian ini menunjukkan bahwa } \\
\text { proporsi jumlah responden pria }\end{array}$} \\
\hline
\end{tabular}


yang cukup signifikan, yaitu sebanyak $71 \%$ pria dan $29 \%$ wanita. Sedangkan umur dari responden sampel penelitian yang masih berada pada kategori usia millennial sebagian besar berumur 31 - 35 tahun sebanyak 38\% responden, disusul oleh responden 35 - 40 tahun dengan jumlah $35 \%$ responden, lalu usia 25 - 30 tahun dengan jumlah $27 \%$ orang. Posisi pekerjaan responden paling banyak diisi oleh karyawan dengan jumlah $93 \%$ orang, dan sisanya menduduki posisi lebih tinggi seperti Head Divisi sebanyak 4\% dan manager sebanyak $3 \%$. Sebagian besar sampel yang diambil menjadi responden pada perusahaan ini juga sudah bekerja lebih dari tiga tahun, yaitu sebanyak $76 \%$. Selain itu terdapat juga responden yang baru bekerja selama satu sampai tiga tahun sebanyak $23 \%$, dan ada satu orang responden yang baru bekerja kurang dari satu tahun. Informasi lengkap tentang profil sampel responden dapat dilihat lebih jelas pada tabel diatas.

\section{Uji Validitas dan Reliabilitas}

Tabel 2. Outer Loading

\begin{tabular}{|c|c|c|}
\hline Variabel & Indikator & Outer Loading \\
\hline \multirow{4}{*}{$\begin{array}{c}\text { Motivasi } \\
\text { Kerja }\end{array}$} & $\mathrm{H} 2$ & 0.786 \\
\cline { 2 - 3 } & $\mathrm{H} 3$ & 0.786 \\
\cline { 2 - 3 } & $\mathrm{K} 1$ & 0.703 \\
\cline { 2 - 3 } & $\mathrm{K} 2$ & 0.737 \\
\cline { 2 - 3 } & $\mathrm{P} 1$ & 0.675 \\
\hline \multirow{4}{*}{$\begin{array}{c}\text { Kepuasan } \\
\text { Kerja }\end{array}$} & $\mathrm{A} 1$ & 0.755 \\
\cline { 2 - 3 } & $\mathrm{PK} 1$ & 0.793 \\
\cline { 2 - 3 } & $\mathrm{PK} 3$ & 0.774 \\
\cline { 2 - 3 } & $\mathrm{PE} 1$ & 0.683 \\
\cline { 2 - 3 } & $\mathrm{PE} 2$ & 0.811 \\
\hline \multirow{3}{*}{$\begin{array}{c}\text { Komitme } \\
\mathrm{n}\end{array}$} & $\mathrm{PE} 3$ & 0.801 \\
\cline { 2 - 3 } Organisas & $\mathrm{KE} 1$ & 0.794 \\
\cline { 2 - 3 } $\mathrm{i}$ & $\mathrm{KE} 3$ & 0.641 \\
\cline { 2 - 3 } & $\mathrm{KB} 1$ & 0.785 \\
\cline { 2 - 3 } & $\mathrm{KB} 2$ & 0.684 \\
\cline { 2 - 3 } & $\mathrm{KB} 3$ & 0.860 \\
\hline
\end{tabular}

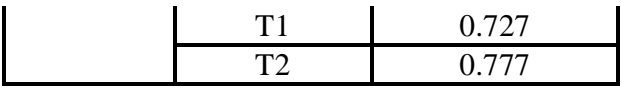

Tabel tiga menunjukkan hasil uji validitas. Indikator yang digunakan untuk mengukur konstruk penelitian dinyatakan valid pada saat nilai Outer Loading lebih besar dari 0.5. Maka model pengukuran yang diusulkan berpotensi untuk diuji lebih lanjut. Berdasarkan hasil dari tabel uji validitas diatas, didapat bahwa semua indikator pada penelitian ini menunjukkan hasil yang valid karena memiliki nilai Outer Loading diatas 0.5 dan dapat diuji lebih lanjut.

Tabel 3. AVE

\begin{tabular}{|c|c|c|}
\hline Variabel & $\begin{array}{c}\text { Average } \\
\text { Variance } \\
\text { Extracted } \\
\text { (AVE) }\end{array}$ & Keterangan \\
\hline Motivasi Kerja & 0.545 & Valid \\
\hline Kepuasan Kerja & 0.594 & Valid \\
\hline $\begin{array}{c}\text { Komitmen } \\
\text { Organisasi }\end{array}$ & 0.571 & Valid \\
\hline
\end{tabular}

Tabel diatas memuat nilai Average Variance Extracted (AVE) pada setiap masing masing variabel hasil analisis. Semua nilai AVE tersebut berada diatas nilai minimum yang disyaratkan, yaitu di atas 0.5 (Ghozali \& Latan 2015; Hair et al., 2014). Maka dari itu nilai AVE untuk semua variabel telah memenuhi persyaratan validitas konvergen.

Tabel 4. Nilai Hubungan Antar

Variabel Penelitian

\begin{tabular}{|c|c|c|c|}
\hline Variabel & $\begin{array}{c}\text { Kepuasa } \\
\text { n Kerja }\end{array}$ & $\begin{array}{c}\text { Komitme } \\
\mathrm{n}\end{array}$ & $\begin{array}{c}\text { Motivas } \\
\text { i Kerja }\end{array}$ \\
\hline
\end{tabular}




\begin{tabular}{|c|c|c|l|}
\hline & & $\begin{array}{c}\text { Organisas } \\
\mathrm{i}\end{array}$ & \\
\hline $\begin{array}{c}\text { Kepuasan } \\
\text { Kerja }\end{array}$ & 0.771 & 0.756 & \\
\hline $\begin{array}{c}\text { Komitme } \\
\mathrm{n} \\
\begin{array}{c}\text { Organisas } \\
\mathrm{i}\end{array}\end{array}$ & 0.741 & 0.543 & 0.738 \\
\hline $\begin{array}{c}\text { Motivasi } \\
\text { Kerja }\end{array}$ & 0.596 & \\
\hline
\end{tabular}

Selanjutnya tabel diatas menunjukkan hasil perhitungan nilai akar kuadrat AVE dan nilai hubungan antar variabel - variabel pada penelitian ini. Analisis dilakukan dengan menggunakan persyaratan metode Fornell Larcker, dimana nilai akar kuadrat lebih besar daripada nilai hubungan antar variabel.

Tabel 5. Composite Reliability

\begin{tabular}{|c|c|c|}
\hline Variabel & $\begin{array}{c}\text { Composite } \\
\text { Reliability }\end{array}$ & Keterangan \\
\hline Motivasi Kerja & 0.857 & Reliabel \\
\hline Kepuasan Kerja & 0.897 & Reliabel \\
\hline $\begin{array}{c}\text { Komitmen } \\
\text { Organisasi }\end{array}$ & 0.902 & Reliabel \\
\hline
\end{tabular}
bahwa semua variabel menunjukkan hasil uji reliabilitas yang sangat baik. Terlihat bahwa ketiga variabel dalam penelitian ini memiliki nilai composite reliability lebih besar dari 0.7 yang menunjukkan bahwa ketiga variabel reliabel (Ghozali \& Latan 2015; Hair et al., 2014). Sehingga dapat disimpulkan bahwa alat penelitian berupa kuesioner yang digunakan dalam penelitian ini konsisten dan reliabel.

\section{Inner Model}

Tabel 6. $R$ Square

\begin{tabular}{|c|c|c|}
\hline & $R$ Square & $R$ Square Adjusted \\
\hline Komitmen Organisasi & 0.564 & 0.555 \\
\hline \multicolumn{2}{|c|}{ Pada perhitungan Inner }
\end{tabular}

Model, dilakukan pengukuran multikolinearitas untuk mengetahui adanya kecenderungan kolinearitas pada hubungan antara variabel independen yang ada. Pada pengukuran $R$-Square yang dilakukan untuk mengetahui seberapa jauh variabel independen dalam menjelaskan variabel dependen, diketahui bahwa Pengaruh Motivasi Kerja dan Kepuasan Kerja terhadap Komitmen Organisasi adalah sebesar $56.4 \%$. Nilai sisanya sebesar $43.6 \%$ dijelaskan dengan variabel - variabel lain diluar dari kedua variabel yang digunakan di dalam penelitian ini. Tabel 7. VIF

\begin{tabular}{|c|c|}
\hline \multicolumn{1}{|c|}{ Variabel } & Komitmen Organisasi \\
\hline Kepuasan Kerja & 1.551 \\
\hline Motivasi Kerja & 1.551 \\
\hline \multicolumn{2}{|c|}{ Tabel delapan merupakan }
\end{tabular}

Tabel delapan merupakan hasil pengujian multikolinearitas yang dilakukan dengan melihat nilai dari Variance Inflation Factor atau VIF dengan tujuan untuk mengetahui apakah ada kecenderungan collinearity pada variabel independen. Uji multikolinearitas digunakan untuk memprediksi variabel dependen dalam sebuah model statistik dimana yang paling efektif yang ditentukan oleh setiap variabel independen. Nilai VIF harus berada dibawah 5 menurut Hair et al. (2014), karena jika melebihi nilai tersebut, maka model dalam 
penelitian ini mengalami multikolinearitas.

\section{Uji Hipotesis}

Setelah melakukan pengujian untuk kesesuaian dari model maka selanjutnya pengujian hipotesis penelitian dapat dilakukan. Pengujian hipotesis dalam penelitian ini menggunakan metode Structural Equation Model (SEM) dibantu dengan software SmartPLS 3.0. Hipotesis dasar dalam penelitian ini dilakukan dengan membandingkan besarnya t-tabel dan t-hitung. Alpha yang digunakan yaitu $0.05(5 \%)$ maka nilai t-hitung nya adalah 1.65 . Jika nilai t-tabel lebih kecil dari 1.65 maka hipotesis ditolak dan tidak memiliki pengaruh. Sebaliknya jika t-tabel lebih besar dari 1.65 maka hipotesis diterima dan memiliki pengaruh antara variabel yang diuji.

Tabel 8. Uji Hipotesis

\begin{tabular}{|l|c|c|c|c|}
\hline & $\begin{array}{c}\text { Origin } \\
\boldsymbol{a l} \\
\text { Sampl } \\
\boldsymbol{e}\end{array}$ & $\begin{array}{c}\boldsymbol{T} \text { - } \\
\text { Statisti } \\
\text { cs }\end{array}$ & $\begin{array}{c}\boldsymbol{P} \text { - } \\
\text { Valu } \\
\boldsymbol{e s}\end{array}$ & $\begin{array}{c}\text { Keterang } \\
\text { an }\end{array}$ \\
\hline $\begin{array}{l}\text { Motivasi } \\
\text { Kerja } \rightarrow \\
\text { en } \\
\text { Organitm } \\
\text { asi }\end{array}$ & 0.157 & 1.652 & $\begin{array}{c}0.04 \\
9\end{array}$ & $\begin{array}{c}\text { Pukup } \\
\text { Signifika } \\
\text { n }\end{array}$ \\
\hline $\begin{array}{l}\text { Kepuasa } \\
\text { n Kerja } \\
\rightarrow\end{array}$ & & 8.669 & 0.00 & $\begin{array}{c}\text { Positif - } \\
\text { Kignifika } \\
\text { Komitm } \\
\text { en } \\
\text { Organis } \\
\text { asi }\end{array}$
\end{tabular}

\section{Pengaruh Motivasi Kerja dengan Komitmen Organisasi}

Berdasarkan hasil uji hipotesis diatas, didapat bahwa untuk hubungan antara motivasi kerja dan komitmen organisasi memiliki nilai t-statistik sebesar 1.652 lebih besar dari nilai t-hitung yaitu 1.65. Artinya hipotesis 1 didukung oleh data penelitian. Nilai original sample adalah 0.157 dan bernilai positif. Hal ini menunjukkan bahwa variabel motivasi kerja memiliki hubungan yang searah dengan variabel komitmen organisasi. Dimana setiap peningkatan poin motivasi kerja menghasilkan kenaikan sebesar 0.157 persen untuk komitmen organisasi dengan asumsi variabel lainnya dianggap konstan. Sementara itu, nilai $p$ value adalah 0.049 lebih kecil dari 0.05 namun cukup dekat dengan 0.05 sehingga artinya pengaruh kedua variabel masih tergolong cukup signifikan. Oleh karena itu, kesimpulan dari hasil uji hipotesis 1 menunjukkan bahwa adanya pengaruh motivasi kerja yang cukup signifikan dan berpengaruh secara positif terhadap komitmen organisasi. Dari hasil kuesioner ditemukan bahwa indikator Harapan dengan kode H3 memberikan kontribusi besar untuk motivasi kerja dengan komitmen organisasi.

Hasil penelitian ini didukung dengan hasil dari penelitian sebelumnya yang dilakukan oleh Srivastava, S. K., \& Barmola, K. C., (2012) yang mengatakan bahwa karyawan yang berkomitmen cenderung menerima motivasi di tempat kerja dan dihargai atas prestasi yang baik. Selain itu, hasil dari penelitian yang dilakukan oleh Hanaysha, J. R., \& Majid, M. (2018) juga sejalan dengan hasil penelitian ini 
yaitu adanya efek dari motivasi karyawan terhadap komitmen organisasi yang positif dan signifikan secara statistik.

\section{Pengaruh Kepuasan Kerja dengan Komitmen Organisasi}

Berdasarkan tabel hasil uji hipotesis diatas maka didapat bahwa hubungan antara kepuasan kerja dengan komitmen organisasi memiliki nilai t-statistik sebesar 8.669 lebih besar dari nilai t-hitung yaitu 1.65. Artinya hipotesis 2 penelitian ini didukung kuat oleh data penelitian. Nilai original sample adalah 0.647 dan bernilai positif. Hal ini menunjukkan bahwa variabel kepuasan kerja memiliki hubungan yang juga searah dengan variabel komitmen organisasi. Dimana setiap peningkatan poin kepuasan kerja menghasilkan kenaikan sebesar 0.647 persen untuk komitmen organisasi dengan asumsi yang sama yaitu variabel lainnya dianggap konstan.

Kemudian nilai p-value untuk hipotesis 2 adalah 0.000 lebih kecil dari 0.05 yang menunjukkan hasil yang signifikan. Oleh karena itu, kesimpulan dari uji hipotesis 2 menunjukkan bahwa kepuasan kerja memiliki pengaruh yang positif dan signifikan terhadap komitmen organisasi. Atasan/rekan kerja dengan kode A1 merupakan indikator dari variabel Kepuasan Kerja dengan pengaruh paling signifikan dalam pengaruh kepuasan kerja dengan komitmen organisasi.

Hasil penelitian ini juga didukung oleh penelitian yang telah dilakukan sebelumnya.
Penelitian yang dilakukan oleh Prasetio et al. (2017) dimana hasilnya menunjukkan bahwa jika kepuasan kerja karyawan terpenuhi maka komitmen organisasi mereka juga bisa ditingkatkan. Hal ini karena kepuasan kerja memiliki hubungan yang kuat dengan komitmen organisasi.

\section{PENUTUP}

\section{Kesimpulan}

Motivasi kerja mempunyai nilai positif dan cukup signifikan terhadap komitmen organisasi pada karyawan yang berada di generasi millenial di PT Megaindo Gemilang Lestari, Jakarta. Hal tersebut memiliki arti jika motivasi kerja meningkat maka komitmen organisasi karyawan millenial juga akan ikut meningkat walau tidak terlalu signifikan.

Kepuasan kerja berpengaruh positif dan signifikan terhadap komitmen organisasi pada karyawan atau pekerja generasi millenial di PT Megaindo Gemilang Lestari, Jakarta. Hal tersebut menandakan semakin meningkatnya kepuasan kerja generasi millenial maka semakin tinggi tingkat komitmen organisasi mereka terhadap perusahaan.

\section{Keterbatasan}

Jumlah sampel penelitian yang terbatas akibat adanya pandemi Covid-19. Hal tersebut menyebabkan banyak karyawan PT Megaindo Gemilang Lestari dirumahkan dalam jangka waktu waktu yang cukup lama sehingga tidak semua karyawannya bisa dijangkau.

Dampak dari pandemi ini juga membuat adanya perubahan perspektif dari karyawan terhadap perusahaan karena kebijakan yang 
berubah untuk menyesuaikan dengan situasi pandemi. Sehingga hasil dari penelitian ini dapat dikatakan bias dan ikut terpengaruh oleh situasi pandemi.

Tidak semua variabel yang memenuhi komitmen organisasi telah diukur, contohnya seperti budaya kerja di perusahaan, dan pengaruh latar belakang dari setiap karyawan terhadap budaya yang diterapkan pada perusahaan yang tidak diukur dalam penelitian ini.

\section{Saran untuk Penelitian}

Selanjutnya

Saran untuk penelitian selanjutnya dapat ditambahkan variabel lainnya yang dapat mempengaruhi komitmen organisasi seperti sistem penghargaan, budaya organisasi, stres kerja, loyalitas, dan lainnya.

Selain itu dalam penelitian selanjutnya sampel penelitian yang diambil dapat lebih bervariatif dengan mengambil sampel pada perusahaan sejenis di bidang atau industri yang sama. Sehingga hasil pada penelitian yang dilakukan dapat menjadi lebih baik serta representatif.

\section{Saran untuk PT Megaindo Gemilang Lestari}

PT Megaindo Gemilang Lestari sebaiknya terus meningkatkan serta mempertahankan motivasi kerja dan khususnya dari segi kepuasan kerja dari karyawan generasi millenialnya agar mereka memiliki komitmen organisasi yang tinggi terhadap perusahaan.

Dilihat dari nilai AVE dimana variabel kepuasan kerja memiliki signifikansi tertinggi kepada komitmen organisasi, dan indikator yang paling mempengaruhi kepuasan kerja adalah tunjangan dan gaji yang diberikan. Sama halnya indikator tersebut mempengaruhi motivasi kerja karyawan, maka dari itu perusahaan sebaiknya juga memperhatikan hal tersebut karena dianggap sebagai pengaruh tertinggi oleh karyawan.

Nilai P-Value dari uji signifikansi motivasi kerja dengan komitmen organisasi sebesar 0.49 yang mendekati nilai tidak signifikan yaitu >0.5. Hal ini menunjukkan bahwa PT MGL sebaiknya meningkatkan tingkat motivasi kerja karyawannya agar komitmen kerja karyawan semakin tinggi.

\section{DAFTAR PUSTAKA}

Ahmed, M. (2017). Estimating the Impact of Need Fulfillment on Human Motivation According to Maslow's Hierarchy of Needs (Doctoral dissertation, University of Akron).

Allen, N. J. ad Meyer, J. P. (1990). The measurement and antecedents of affective, continuance, and normative commitment to the organization. Journal of Occupational Psychology.

Becton, J. B., Walker, H. J., \& JonesFarmer, A. (2014). Generational differences in workplace behavior. Journal of Applied Social Psychology, 44(3), 175-189.

Buchko, A. A., Weinzimmer, L. G. and Sergeyev, A. V. (1998). Effects of cultural context on the antecedents, correlates, and consequences of organizational commitment: A study of Russian workers. Journal of Business Research, 43, 109116. 
Calk, R., \& Patrick, A. (2017). Millennials through the looking glass: Workplace motivating factors. The Journal of Business Inquiry, 16(2), 131-139.

Colquitt, Jason A., Jeffery A. LePine dan Michael J. Wesson. (2018). Organizational Behavior: Improving performance and commitment in the workplace second edition. New York: McGraw Hill.

Dimock, M. (2019). Defining generations: Where Millennials end and Generation $\mathrm{Z}$ begins. Pew Research Center, 17(1), 17.

Diskienė, D., Stankevičienė, A., \& Jurgaitytè, N. (2017, December). Challenges for human resource department: The case of millennials in the workplace. In ECMLG 2017 13th European Conference on Management, Leadership and Governance: ECMLG.

Ghozali, I., \& Latan, H. (2015). Partial least squares: Konsep, teknik, dan aplikasi menggunakan program SmartPLS 3.0, Universitas Diponegoro Semarang, ed. 2, Badan Penerbit Undip.

Hana, Urbancová \& Linhartová Lucie. (2011). Staff Turnover as a Possible Threat to Knowledge Loss. Journal of Competitiveness, Issue 3/2011.

Hanaysha, J. R., \& Majid, M. (2018). Employee motivation and its role in improving the Nawawi, Hadari. (2008). Manajemen Sumber Daya Manusia (1, Cet.7). Yogyakarta: Gadjah Mada University Press, 351359. productivity and organizational commitment at higher education institutions. Journal of Entrepreneurship and Business, 6(1), 17-28.

Handoko, D. S., \& Rambe, M. F. (2018).

Pengaruh

Pengembangan Karir dan Kompensasi terhadap Komitmen Organisasi Melalui Kepuasan Kerja. Maneggio: Jurnal Ilmiah Magister Manajemen, 1(1), 31-45.

Luthans, Fred. (2011). Organizational Behavior : An Evidence-Based Approach / Fred Luthans (12th ed.). New York: McGraw-Hill/Irwin.

Maume, D. J., (2006). "Gender differences in taking vacation time. Work and Occupations", 33(2), 161-190.

Maxwell, G. and Steele, G. (2003), "Organisational commitment: a study of managers in hotels", International Journal of Contemporary Hospitality Management, Vol. 15 No. 7.

Meriac, J. P., Woehr, D. J., \& Banister, C. (2010). Generational differences in work ethic: An examination of measurement equivalence across three cohorts. Journal of Business and Psychology, 25(2), 315-324.

Meyer, J. P. and Allen, N. J. (1997). Commitment in the Workplace Theory Research and Application. California: Sage Publications.

Prasetio, A. P., Yuniarsih, T., \& Ahman, E. (2017). Job Satisfaction, Organizational Commitment, and Organizational Citizenship 
Behaviour in State-owned Banking, 5(1), 32-38.

Robbins, Stephen P. (2017). Organizational Behavior / Stephen P. Robbins, Timothy A. Judge (17th ed. (global edition)). Essex: Pearson.

Srivastava, S. K., \& Barmola, K. C. (2012). Role of motivation in higher productivity. Management Insight, 7(1), 8899.

Thompson, C., \& Gregory, J. B. (2012). Managing millennials: A framework for improving attraction, motivation, and retention. The psychologistmanager journal, 15(4), 237246.
Wargo, Sugleris, M., Robbins, W., Lane, C. J., \& Phillips, L. R. (2018). Job satisfaction, work environment and successful ageing: Determinants of delaying retirement among acute care nurses. Journal of advanced nursing, 74(4), 900913.

Weirich, B. (2017). A millennial leader's views on the millennial workforce. Nurse Leader, 15(2), 137-139.

Wood, J. C. (2019). Millennials in the workplace: mystery or magic?. Dispute Resolution Journal, 74(1), 111-120. 